\title{
Catalytic Chemoselective Sulfimidation with an Electrophilic [Co'II(TAML)]--Nitrene Radical Complex
}

\author{
Nicolaas P. van Leest, ${ }^{[a]}$ Jarl Ivar van der Vlugt ${ }^{[a],[b]}$ and Bas de Bruin ${ }^{*,[a]}$
}

\author{
[a] N. P. van Leest, Prof. Dr. Ir. J. I. van der Vlugt, Prof. Dr. B. de Bruin \\ Homogeneous, Supramolecular and Bio-Inspired Catalysis Group \\ van 't Hoff Institute for Molecular Sciences \\ University of Amsterdam (UvA) \\ Science Park 904, 1098 XH Amsterdam, The Netherlands \\ E-mail: b.debruin@uva.nl \\ [b] Current address Prof. Dr. Ir. J. I. van der Vlugt \\ Bioinspired Coordination Chemistry \& Homogeneous Catalysis Group \\ Institute of Chemistry \\ Carl von Ossietzky University Oldenburg \\ Carl-von-Ossietzky-Strasse 9-11. 26129 Oldenburg, Germany
}

\begin{abstract}
The cobalt species $\mathbf{P P h}_{4}\left[\mathrm{Co}^{\text {"II' }}\left(\mathrm{TAML}^{\text {red }}\right)\right]$ is a competent and stable catalyst for the sulfimidation of (aryl)(alkyl)-substituted sulfides with iminoiodinanes reaching turnover numbers up to 900 and turnover frequencies of $640 \mathrm{~min}^{-1}$ under mild and aerobic conditions. The sulfimidation proceeds in a highly chemoselective manner, even in the presence of alkenes or weak $\mathrm{C}-\mathrm{H}$ bonds, as supported by inter- and intramolecular competition experiments. Functionalization of the sulfide substituent with various electrondonating and electron-withdrawing arenes and several alkyl, benzyl and vinyl fragments is tolerated, with up to quantitative product yields. Sulfimidation of phenyl allyl sulfide led to [2,3]-sigmatropic rearrangement of the initially formed sulfimide species to afford the corresponding $\mathrm{N}$-allyl-S-phenyl-thiohydroxylamines as attractive products. Mechanistic studies suggest that the actual nitrene transfer to the sulfide proceeds via (previously characterized) electrophilic nitrene-radical intermediates that afford the sulfimide products via electronically asynchronous transition states, in which SET from the sulfide to the nitrene-radical complex precedes $\mathrm{N}-\mathrm{S}$ bond formation in a single concerted process.
\end{abstract}

\section{Introduction}

Sulfimides (RN=SR'R"), and their oxidized analogues sulfoximines (RN=SOR'R"), are important substructures in several pharmaceuticals as well as chemicals used for crop protection. ${ }^{1}$ Moreover, the sulfimide and sulfoximide analogues of known sulfoxide-based drugs were found to retain their druglike properties in e.g. ATR targeted cancer therapy ${ }^{2}$ and often displayed enhanced aqueous solubility, cell permeability and metabolic stability. Specific ( $N$-arylsulfonyl)sulfimide-based drugs $\left(\mathrm{ArSO}_{2} \mathrm{~N}=\mathrm{SR} \mathrm{R}^{\prime \prime}\right.$, with $\mathrm{R}^{\prime}=$ alkyl and $\mathrm{R}^{\prime \prime}=$ aryl) have been found to inhibit osteoclastogenesis and to bind to proteins (e.g. pirin), causing inhibition of melanoma cell migration. ${ }^{3}$

Numerous synthetic methodologies ${ }^{1}$ for the $S$-imidation of sulfides and sulfoxides have been developed after the synthesis of $S$-vinylsulfimides using chloramine-T as $\mathrm{N}$-group transfer agent in $1979,{ }^{4}$ and catalysts based on copper, ${ }^{5}$ manganese, ${ }^{6}$ ruthenium, ${ }^{7}$ iron, ${ }^{8}$ rhodium, ${ }^{9}$ silver ${ }^{10}$ as well as a P450-type enzyme ${ }^{11}$ have been reported for (asymmetric) sulfimidation and sulfoximidation. $\mathrm{N}$-Haloamides (and derivatives), (in situ prepared) iminoiodinanes, azides, and heterocyclic nitrene precursors have all been used as imidation reagents. ${ }^{1 a}$ In addition, uncatalyzed sulfimidation and sulfoximidation of $S$-alkyl and $S$-aryl sulfides with in situ formed PhINNs (Ns = nosyl, 4(nitrophenyl)sulfonyl) occurs at prolonged heating in $\mathrm{MeCN}$ (16 h, $\left.82{ }^{\circ} \mathrm{C}\right){ }^{12}$ and the $\mathrm{I}_{2}$-catalyzed sulfimidation is also known, producing $\mathrm{N}$-tosylsulfimides (tosyl = Ts, 4(methylphenyl)sulfonyl) at room temperature. ${ }^{13}$ Alternatively, $\mathrm{N}, \mathrm{O}$-group exchange to form sulfimides from sulfoxides can be achieved with the zwitterionic Burgess reagent $\left({ }^{+} \mathrm{NEt}_{3}-\mathrm{SO}_{2}-\mathrm{N}^{-}-\right.$ CO-OR). ${ }^{14}$

Surprisingly, cobalt-catalyzed nitrene transfer to sulfur atoms remains largely unexplored. While a single example of $\left[\mathrm{Co}\left(\mathrm{ClO}_{4}\right)_{2}\right]$-catalyzed sulfoximidation of methyl phenyl sulfoxide with (in situ formed) PhINNs has been reported, ${ }^{15}$ there are no reported examples of cobalt-catalyzed sulfimidation of sulfides, to the best of our knowledge. Given recent developments in cobalt-catalyzed $N$-group transfer reactions, ${ }^{16,17,18}$ we decided to investigate cobalt-catalyzed sulfimidation via nitrene transfer to sulfides focusing on chemoselective transformations in the presence of other nitrene-accepting functional groups (alkenes and weak $\mathrm{C}-\mathrm{H}$ bonds). For this purpose we decided to investigate the reactivity of the previously characterized nitrene radical adducts of a cobalt-TAML complex ${ }^{19}($ TAML $=$ TetraAmido Macrocyclic Ligand ${ }^{20}$ ) towards sulfides. Based on the reactivity displayed by this Co-platform in alkene aziridination catalysis, ${ }^{18}$ we envisaged that this cobalt platform could also be a suitable candidate for chemoselective catalytic sulfimidation reactions.

During our previous studies we identified the TAML ligand as being redox-active on cobalt (see Scheme $1 \mathrm{~A}$ for nomenclature and structures) and we demonstrated that $\mathbf{P P h}_{4}\left[\mathrm{Co}^{\text {"II }}\left(\mathrm{TAML}^{\text {red }}\right)\right]$ is selectively converted to the catalytically active bis-nitrene radical complexes $\mathbf{P P h}_{4}\left[\mathbf{C o}^{\prime \prime \prime}\left(\mathbf{T A M L}^{\mathrm{q}}\right)(\mathbf{N R})_{2}\right](\mathrm{R}=$ nosyl or tosyl, Scheme 1B) upon reaction with excess iminoiodinane during the aziridination reactions. ${ }^{18,19}$ Moreover, we reported that productive $\mathrm{C}-\mathrm{N}$ bond formation in the aziridination reaction occurs via unusual electronically asynchronous transition states in which single-electron transfer (SET) from styrene to the involved nitrene-radical complex precedes $\mathrm{N}-\mathrm{C}$ bond formation in a single concerted process (Scheme 1C). The formation of the $\mathrm{C}-\mathrm{N}$ bond does not occur via nitrene radical attack (as might be 
expected), but rather via nucleophilic attack of the nitrene lonepair onto a (partially) formed styrene radical cation as a result of initial substrate-to-ligand single-electron transfer. This process is coupled to TAML-to-cobalt and cobalt-to-nitrene single-electron transfer and a cobalt centered spin flip.
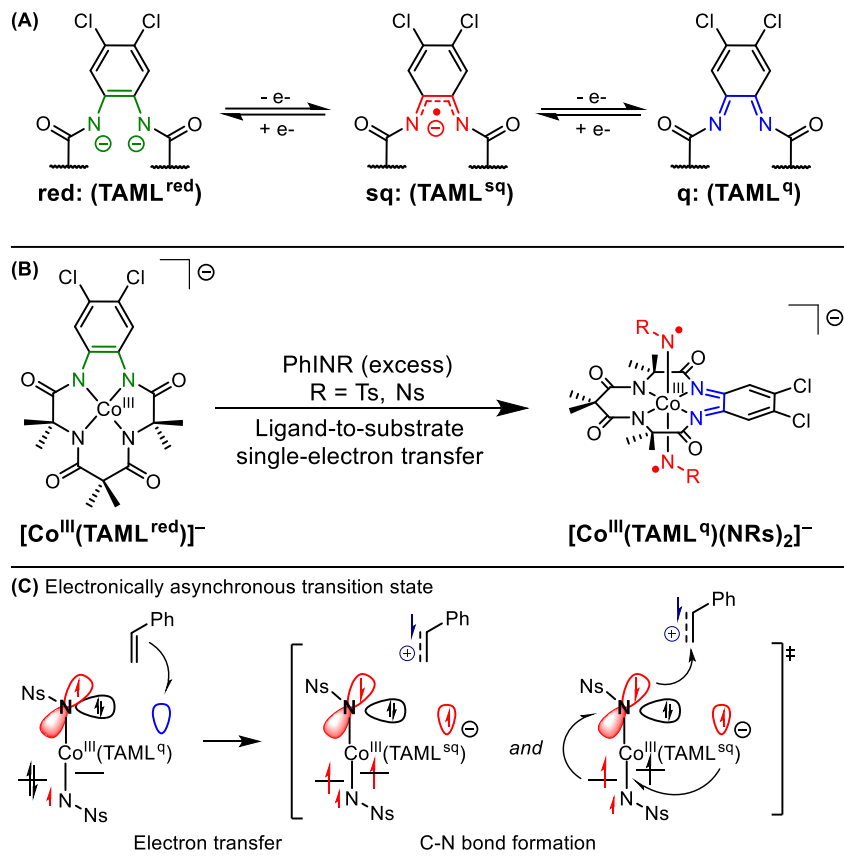

Scheme 1. (A): Oxidation states for the TAML scaffold. (B): previously reported bis-nitrene radical formation on [Co'll'(TAMLred)]- (bottom). ${ }^{19}$ (C): Electronically asynchronous transition state for $\mathrm{C}-\mathrm{N}$ bond formation in aziridination with $\left[\mathrm{Co}^{\prime \prime \prime}\left(\mathrm{TAML}^{\mathrm{q}}\right)(\mathrm{NNs})_{2}\right]^{-} .^{18}$

As substrate-to-ligand single-electron transfer precedes bond formation in these electronically asynchronous transition states, we reasoned that compounds having low one-electron oxidation potentials might be suitable substrates for nitrene transfer catalysis with $\mathbf{P P h}_{4}\left[\mathbf{C o}^{\prime \prime \prime}\left(\mathbf{T A M L}^{\text {red }}\right)\right]$ under mild and aerobic conditions. Moreover, we hypothesized that this reactivity could allow for selective (late stage) nitrene transfer catalysis when the chemoselectivity is determined by the oxidation potential of the functional group (i.e. preferred nitrene transfer to the functionality that is most easily oxidized). For example, one-electron oxidation of methyl phenyl sulfide (thioanisole, $E_{1 / 2}=+1.56 \mathrm{~V}$ vs SCE) ${ }^{21 a}$ occurs at a lower potential than styrene oxidation $\left(E_{1 / 2}=+1.90 \mathrm{~V} v S \mathrm{SCE}\right)^{21 \mathrm{~b}}$ and would therefore lead to preferential sulfimidation over aziridination. Hence, this mechanism of nitrene transfer to sulfides could be particularly powerful for a chemoselective catalytic sulfimidation protocol in the presence of alkenes and weak $\mathrm{C}-\mathrm{H}$ bonds, which are both susceptible to reactions with nitrene radicals ${ }^{16}$ but typically have higher oxidation potentials than sulfides.

Related iron- ${ }^{22}$ and manganese-TAML ${ }^{23}$ complexes were found be active in stoichiometric nitrene transfer to thioanisole derivatives, but catalytic activity has not been reported to date. Thus, inspired by the catalytic activity of $\mathbf{P P h}_{4}\left[\mathbf{C o}^{\text {"II' }}\left(\mathrm{TAML}^{\text {red }}\right)\right.$ ] under aerobic conditions in the aziridination of alkenes, we decided to explore its catalytic activity for sulfimidation reactions. Given the known reactivity of [Co"'(TAML ${ }^{\text {red }}$ ) $]^{-}$for aziridination chemistry, we also investigated whether chemoselective sulfimidation reactions could be performed in presence of alkenes and weak $\mathrm{C}-\mathrm{H}$ bonds. ${ }^{18}$ Specifically, we report the following findings in this work:

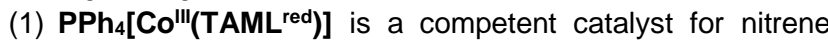
transfer to sulfides under mild conditions.

(2) Nitrene transfer occurs chemoselectively for sulfimidation in the presence of alkenes and weak $\mathrm{C}-\mathrm{H}$ bonds.

(3) Nitrene transfer proceeds via electrophilic behavior of the nitrene intermediates, involving electronically asynchronous transition states in which SET from the sulfide to the nitrene radical complex precedes $\mathrm{N}-\mathrm{S}$ bond formation in a single concerted process.

The main findings of this work are summarized in Scheme 2.

(A) Previous work on homogeneously catalyzed sulfimidation

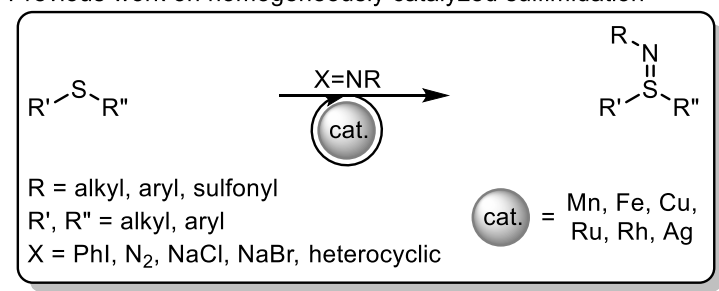

(B) This work: cobalt-catalyzed sulfimidation

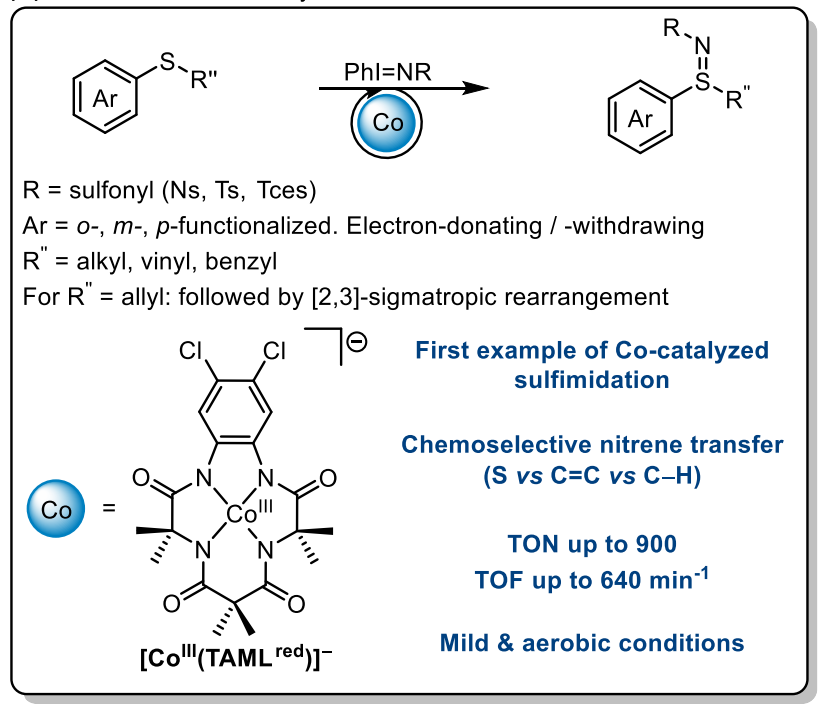

Scheme 2. (A): Previous work on homogeneously catalyzed sulfimidation. ${ }^{5-10}$ (B): Cobalt-catalyzed sulfimidation approach presented in this paper.

\section{Results and Discussion}

Optimization of the reaction conditions.

To establish the catalytic competence of $\mathbf{P P h}_{4}$ [Co"'(TAML $\left.{ }^{\text {red }}\right)$ ] we first investigated different classes of sulfides to determine the preferred substrate class for sulfimidation. Thioanisole $\left(E_{1 / 2}=\right.$ $+1.56 \mathrm{~V}$ vs SCE $)^{21 a}$ was cleanly converted to $\mathrm{N}$-(4nitrobenzenesulfonyl)-S-methyl-S-phenylsulfimide $\left(1^{\mathrm{Ns}}\right)$ in $77 \%$ yield under aerobic conditions in 15 minutes at $25^{\circ} \mathrm{C}$ in $\mathrm{CH}_{2} \mathrm{Cl}_{2}$ with 2.5 mol\% $\mathbf{P P h}_{4}\left[\mathrm{Co}^{\text {"I'(TAML }}{ }^{\text {red }}\right.$ )] (entry 1, Table 1). Diphenylsulfide $\left(E_{1 / 2}=+1.79 \mathrm{~V} \text { vs SCE }\right)^{21 \mathrm{~b}, 24}$ only afforded $19 \%$ of the desired product in 15 minutes (longer reaction times lead to higher yields, see Table 3), whilst dimethylsulfide $\left(E_{1 / 2}=+0.91 \mathrm{~V}\right.$ vs SCE) $)^{21 b, 24}$ yielded $40 \%$ of the sulfimide, albeit with $55 \%$ 
conversion of the iminoiodinane to $\mathrm{NsNH}_{2}$ (entry 2 and 3)..$^{25}$ Thiophene $\left(E_{1 / 2}=+1.91 \mathrm{~V} \text { vs SCE}\right)^{21 a}$ (entry 4$)$ was not converted to the corresponding sulfimide at all and also sulfoxides, which have higher oxidation potentials compared to their corresponding sulfides, ${ }^{21}$ were not effectively converted to the sulfoximines (entry 5 and 6 ). These results indicate that (alkyl)(aryl)-substituted sulfides are most effectively converted via $\mathrm{N}$-transfer chemistry due to their relatively low oxidation potentials.

Table 1. Initial substrate screening for the imidation of various sulfides and sulfoxides with PhINNs.

\begin{tabular}{|c|c|c|c|c|c|}
\hline \multirow{2}{*}{$\mathrm{R}^{1-\mathrm{I}_{-}} \cdot \mathrm{R}$} & \multirow{2}{*}{+} & \multirow{2}{*}{$\mathrm{Phl}=\mathrm{NNs}$} & \multirow{2}{*}{\multicolumn{2}{|c|}{$\begin{array}{c}\mathrm{PPh}_{4}\left[\mathrm{Co}^{\text {III }}\left(\mathrm{TAML}^{\text {red }}\right)\right](2.5 \mathrm{~mol} \%) \\
\mathrm{CH}_{2} \mathrm{Cl}_{2}, 25^{\circ} \mathrm{C}, \text { aerobic } \\
-\mathrm{Phl}\end{array}$}} & \multirow{3}{*}{$\begin{array}{c}\mathrm{R}_{\text {N N }} \\
\mathrm{R}^{1-\mathrm{S}} \\
\text { Yield }^{[\mathrm{a}]}\end{array}$} \\
\hline & & & & & \\
\hline Entry & $x$ & $\mathrm{R}^{1}$ & $R^{2}$ & $E_{1 / 2}(\mathrm{~V} v s \mathrm{SCE})^{21}$ & \\
\hline 1 & - & $\mathrm{Ph}$ & $\mathrm{Me}$ & +1.56 & $77 \%$ \\
\hline 2 & - & $\mathrm{Ph}$ & $\mathrm{Ph}$ & +1.79 & $19 \%$ \\
\hline 3 & - & $\mathrm{Me}$ & $\mathrm{Me}$ & +0.91 & $40 \%[b]$ \\
\hline 4 & - & $-(\mathrm{CH}=\mathrm{C}$ & $\mathrm{I}-\mathrm{CH}=\mathrm{CH})-$ & +1.91 & n.d. \\
\hline 5 & $\mathrm{O}$ & $\mathrm{Ph}$ & $\mathrm{Me}$ & - & $9 \%$ \\
\hline 6 & $\mathrm{O}$ & $\mathrm{Ph}$ & $\mathrm{Ph}$ & - & n.d. \\
\hline
\end{tabular}

Ratio PhINNs: substrate $=1: 1$. Conditions: 15 minutes, $24 \mathrm{mM}$ PhINNs. denotes that $X$ is a lone pair. n.d.: not detected. [a] Yields based on ${ }^{1} \mathrm{H}$ NMR integration using 1,3,5-trimethoxybenzene as an internal standard. [b] $55 \%$ $\mathrm{NsNH}_{2}$ formation observed in ${ }^{1} \mathrm{H}$ NMR

Having established that (alkyl)(aryl)-substituted sulfides are most effectively converted we set out to further optimize the reaction conditions. With the nitrene precursor as the limiting reagent we screened the reaction time and catalyst loading for formation of $1^{\mathrm{Ns}}, \mathbf{1}^{\mathrm{Ts}}$ and $\mathbf{1}^{\mathrm{Tces}}$ from thioanisole and the corresponding iminoiodinane under aerobic conditions at $25{ }^{\circ} \mathrm{C}$ in $\mathrm{CH}_{2} \mathrm{Cl}_{2}{ }^{26}$ Using PhINNs, the highest yield (96\%) of $1^{\mathrm{Ns}}$ was obtained after 30 minutes with 2.5 or $1.0 \mathrm{~mol} \%$

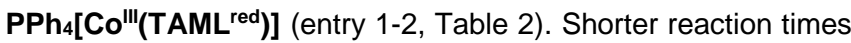
resulted in lower yields (entry 3 and 4). Interestingly, a two-hour reaction using a catalyst loading as low as $0.1 \mathrm{~mol} \%$ still afforded $1^{\text {Ns }}$ in $35 \%$ yield, which corresponds to 350 turnover numbers (TONs). Using PhINTs as the nitrene precursor at 0.1 mol\% catalyst loading produced $1^{\mathrm{Ts}}$ in $64 \%(\mathrm{TON}=640$ and turnover frequency $($ TOF $\left.)=640 \mathrm{~min}^{-1}\right)$ or $90 \%(T O N=900)$ after 1 or 5 minutes, respectively. Using $1.0 \mathrm{~mol} \%$ catalyst and 5 minutes reaction time yielded $1^{\text {Ts }}$ and $1^{\text {Tces }}$ in quantitative (>99\%) or $90 \%$ yield, respectively.

For consistency in the substrate scope screening (performed mainly with PhINTs and PhINNs, vide infra), we selected 1.0 mol\% catalyst loading and 30 minutes reaction time as the standard conditions. Control reactions without catalyst (entry 10) did not lead to product formation. The involvement of free ligand $\left(\mathrm{TAMLH}_{4}\right),\left[\mathrm{PPh}_{4}\right]^{+}$or $\mathrm{CoCl}_{2}$ on product formation was excluded (entry 11 ) as $1^{\mathrm{Ns}}$ was obtained in only $2 \%$ yield, thus clearly demonstrating the catalytic behavior of $\mathbf{P P h}_{4}\left[\mathrm{Co}^{\text {"I' }}\left(\mathrm{TAML}^{\mathrm{red}}\right)\right]$.
Table 2. Optimization of the reaction time and catalyst loading for the sulfimidation of thioanisole.

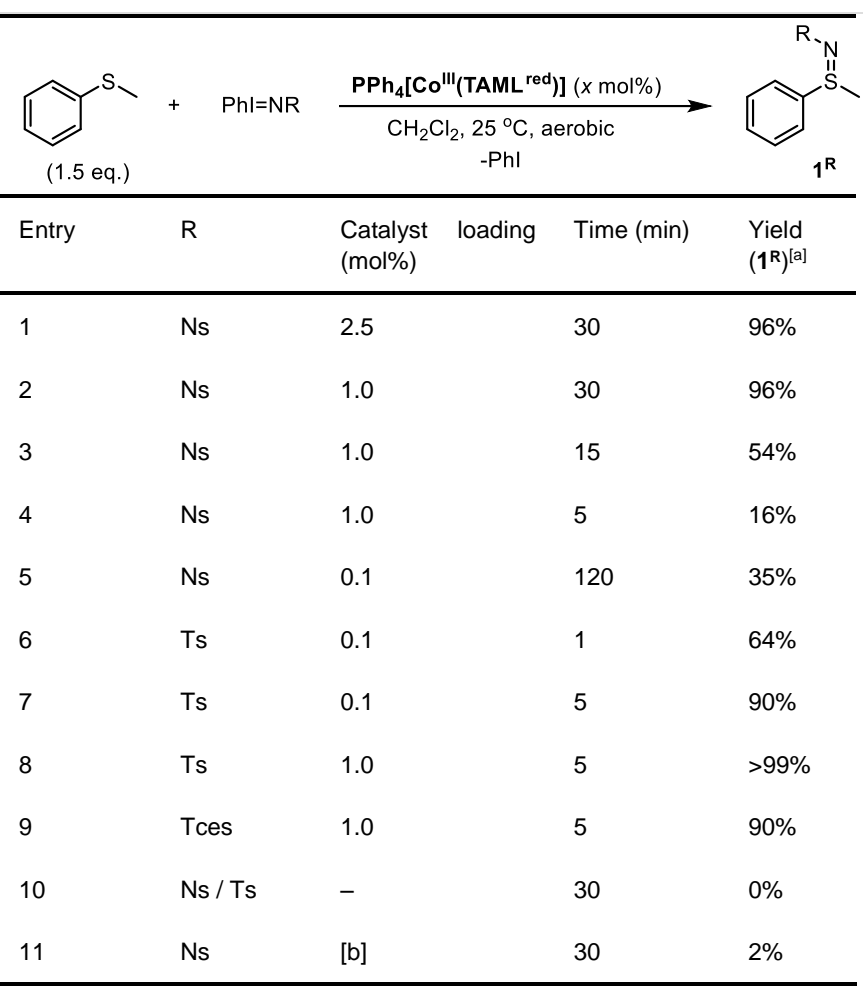

Conditions: 15 minutes, $24 \mathrm{mM}$ PhINNs. [a] Yields based on ${ }^{1} \mathrm{H}$ NMR integration using 1,3,5-trimethoxybenzene as an internal standard. [b] 2.5 mol\% $\left[\mathrm{PPh}_{4}\right] \mathrm{Cl}, \mathrm{TAMLH}_{4}$ or $\mathrm{CoCl}_{2}$ was used.

Chemoselectivity in intermolecular competition reactions. Kinetic competition experiments for nitrene transfer to $\mathrm{S}, \mathrm{C}=\mathrm{C}$ and $\mathrm{C}-\mathrm{H}$ positions were performed to investigate the intermolecular chemoselectivity for nitrene transfer reactions. The reactions were performed with $2.5 \mathrm{~mol} \%$ catalyst loading, which should lead to maximal competition between $\mathrm{C}-\mathrm{H}$ amination or alkene aziridination and sulfimidation, as this was previously reported to be the optimal loading for alkene conversion. ${ }^{18}$ As substrates we selected thioanisole, ethylbenzene, styrene and 4-tert-butyl-styrene (4-tBu-styrene). The latter was included as we previously showed that aziridination of this substrate proceeds much faster than for styrene itself, ${ }^{18}$ thus making it a suitable substrate to study competition between sulfimidation and aziridination. Strikingly, in all cases, including 4-tBu-styrene, we observed $>99 \%$ selectivity for sulfimidation and preservation of the alkene functionality (Table 3, entries 1-2). In absence of thioanisole, aziridination of styrene is strongly favored over $\mathrm{C}-\mathrm{H}$ amination of ethylbenzene (Table 3, entry 3). From these experiments it is clear that the relative reaction rates for nitrene transfer follow the order: $k_{\mathrm{S}}>$ $k_{\mathrm{C}=\mathrm{C}}>k_{\mathrm{C}-\mathrm{H}}$. Switching to diphenylsulfide (entries 4 and 5) afforded $82 \%$ and $83 \%$ selectivity for sulfimidation with PhINNs in competition with aziridination of styrene or 4-tBu-styrene, with the only detected by-product being the aziridine in $16 \%$ yield. The chemoselectivity toward sulfimidation significantly increased (95\%) when using PhINTs (instead of PhINNs), consistent with the higher reactivity of this iminoiodinane in the catalytic system as reflected by shorter reaction times (vide supra). In addition, we performed an intermolecular competition reaction between 
styrene and thioanisole under the previously reported optimal styrene aziridination conditions ${ }^{18}$ with PhINNs $(2.5 \mathrm{~mol} \%$ catalyst loading, $35{ }^{\circ} \mathrm{C}$, total 5 equivalents substrate). This led to formation of $1^{\mathrm{Ns}}$ in $91 \%$ yield, without detectable formation of the aziridine (see Supporting Information).

Table 3. Intermolecular competition experiments to investigate the chemoselectivity for sulfimidation in presence of $\mathrm{C}=\mathrm{C}$ and weak $\mathrm{C}-\mathrm{H}$ bonds.

(1.0 eq)

Ratio A : B : PhINR = $1.5: 1.5: 1.0$. [PhINR] = $24 \mathrm{mM}$. [a] Selectivities based on ${ }^{1} \mathrm{H}$ NMR integration using 1,3,5-trimethoxybenzene as an internal standard. [b] Reactions were stopped before $17 \%$ conversion of $A+B(50 \%$ conversion of PhINNs). [c] After 1 hour (conversion PhINNs = 90\%). [d] After 25 minutes (conversion PhINTs = 33\%).

\section{Chemoselectivity in intramolecular competition reactions.}

Having established the intermolecular chemoselectivity for nitrene transfer to sulfides, we next explored the intramolecular chemoselectivity for sulfimidation in the presence of alkenes and weak $\mathrm{C}-\mathrm{H}$ bonds. Alkene fragments prone to aziridination are highlighted purple in Scheme 3 and reactive $\mathrm{C}-\mathrm{H}$ positions, i.e. with a tabulated ${ }^{27}$ bond dissociation energy (BDE) $\leq 85.0 \mathrm{kcal}$ $\mathrm{mol}^{-1}$ or $85<\mathrm{BDE}<95 \mathrm{kcal} \mathrm{mol}^{-1}$ are marked in green and grey, respectively. We employed $\left.1.0 \mathrm{~mol}_{\%} \mathbf{P P h}_{4}\left[\mathrm{Co}^{\text {"II'(TAML }}{ }^{\text {red }}\right)\right]$ as the catalyst at $25{ }^{\circ} \mathrm{C}$ under aerobic conditions in $\mathrm{CH}_{2} \mathrm{Cl}_{2}$ throughout these studies.
Sulfimidation of para- or meta-methylthioanisole afforded products $2^{\mathrm{Ts}}, 2^{\mathrm{Ns}}, 3^{\mathrm{Ts}}$ and $3^{\mathrm{Ns}}$ in quantitative yield (Scheme 3 ). Interestingly, $\mathbf{2}^{\text {Ts }}$ was also obtained in $>99 \%$ yield at $0{ }^{\circ} \mathrm{C}$, and even significantly lower reaction temperatures $\left(-61{ }^{\circ} \mathrm{C}\right.$ or -78 ${ }^{\circ} \mathrm{C}$ ) still afforded $2^{\text {Ts }}$ after 2 hours in $74 \%$ or $31 \%$ yield. The more electron-rich 4-methoxythioanisole was converted to $3^{\text {Ts }}$ in quantitative yield and the electron-withdrawing para-fluoro- and ortho-chloro-substituted thioanisoles yielded $4^{\text {Ts }}$ and $5^{\text {Ts }}$ in $92 \%$ and $>99 \%$ yield, respectively. We did not observe any transformation of the weakly activated $\mathrm{C}-\mathrm{H}$ positions (highlighted in grey) in these reactions by ${ }^{1} \mathrm{H}$ NMR spectroscopy. Substitution of the methyl group in thioanisole for ethyl or isopropyl selectively afforded $7^{\text {Ts }}(90 \%), 7^{\text {Ns }}(99 \%)$ and $8^{\text {Ts }}(>99 \%)$, as depicted in Scheme 3. The more strongly activated $\alpha-\mathrm{CH}_{2}$ position of benzyl phenyl sulfide or 2-(phenylethyl)-phenylsulfide did not undergo any reaction, with both substrates being selectively converted to $9^{\text {Ts }}$ and $10^{\text {Ts }}$ in $88 \%$ and $79 \%$ yield, respectively.

To investigate intramolecular competition with alkenes, we employed phenyl vinyl sulfide, which afforded selective formation of $11^{\text {ss }}$ in $49 \%$ yield (Scheme 3 ), without any indication for aziridine formation based on ${ }^{1} \mathrm{H}$ NMR spectroscopy. Using phenyl allyl sulfide as the substrate with either PhINTs or PhINNs led to clean formation of $\mathrm{N}$-allyl-S-phenylthiohydroxylamines $13^{\mathrm{Ts}}(78 \%)$ and $13^{\mathrm{Ns}}(65 \%)$, respectively. These products arise from [2,3]-sigmatropic rearrangement of the initially formed $S$-allyl-sulfimides, as reported in literature, ${ }^{5 b, 28}$ and thus indicates the initial $S$-imidation of phenyl allyl sulfide. Again, we did not observe any reaction with the alkene or weak $\mathrm{C}-\mathrm{H}$ position by ${ }^{1} \mathrm{H}$ NMR spectroscopy. Lastly, methyl-(4(phenoxymethyl)-phenyl) sulfane as substrate selectively provided (98\% yield) access to $14^{\mathrm{Ts}}$, which has been studied in the context of cancer research as a drug to bind to the nuclear protein pirin to inhibit melanoma cell migration. ${ }^{3}$

\section{Mechanistic studies.}

To get insight into the electronic effects governing the reactions, a Hammett analysis ${ }^{29}$ was performed by intermolecular competition experiments under standard conditions with PPh 4 [Co'"'(TAML ${ }^{\text {red }}$ )] (1.0 mol\%, aerobic, $25^{\circ} \mathrm{C}, 24 \mathrm{mM}$ PhINTs in $\mathrm{CD}_{2} \mathrm{Cl}_{2}$ ). Compared to the amount of PhINTs, $1.5 \mathrm{eq}$ thioanisole and 1.5 eq of a para-functionalized thioanisole $(\mathrm{X}=$ $\mathrm{Me}$, OMe or $\mathrm{F}$ ) were present. The $k_{\mathrm{x}} / k_{\mathrm{H}}$ ratio was then determined by the relative formation of para-functionalizedsulfimide versus $1^{\text {Ts }}$ (see also $\mathrm{SI}$ ). Plotting $\log \left(k_{\mathrm{x}} / k_{\mathrm{H}}\right)$ versus $\sigma^{+}$ and linear fitting afforded a $\rho^{+}$value of $-0.57\left(R^{2}=0.96\right)$, which indicates positive charge buildup on the sulfide substrate in the transition state and therefore electrophilic behavior of the nitrene intermediates (vide infra). The negative $\rho^{+}$is suggestive for electron transfer from the sulfide to the nitrene complex during or prior to $\mathrm{N}-\mathrm{S}$ bond formation, similar to the previously reported electronically asynchronous transition states $\left(\rho^{+}=-0.80, \rho^{*}=\right.$ 0.14 ) for $\mathrm{C}-\mathrm{N}$ bond formation in $\mathrm{PPh}_{4}\left[\mathrm{Co}^{\text {"II' }}\left(\mathrm{TAML}^{\text {red }}\right)\right]$ catalyzed aziridination reactions. ${ }^{18}$ However, in the present case we observed a higher accuracy by excluding radical delocalization constants $^{30}$ (i.e. $\rho^{*}=0$, see $\mathrm{SI}$ ) in the Hammett analysis. 

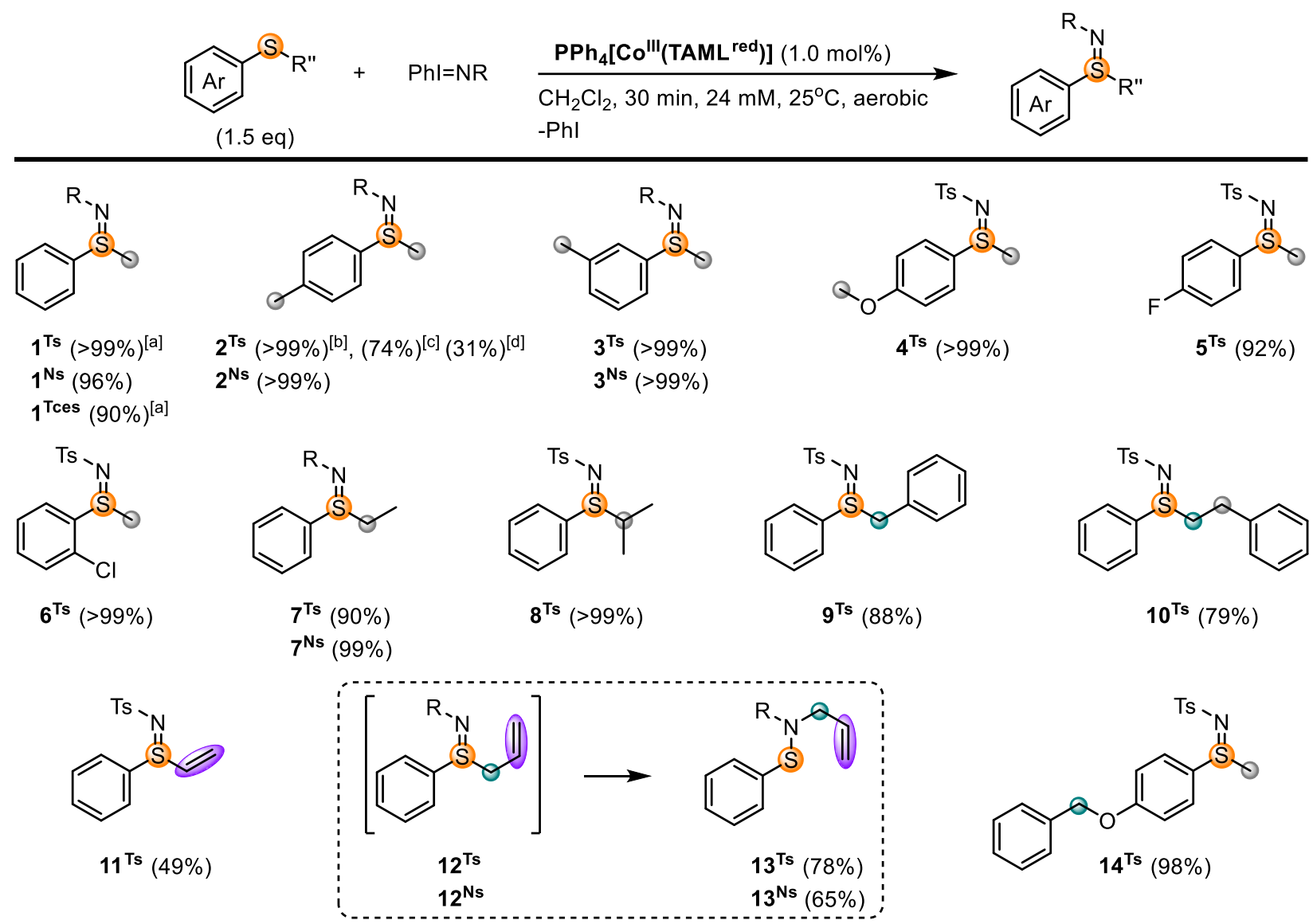

Scheme 3. Substrate scope for the sulfimidation of (alkyl)(aryl)-substituted sulfides with $\mathbf{P P h}_{4}$ [Co'l'(TAML ${ }^{\text {red }}$ ] ] and PhINTs, PhINNs or PhINTces. Yellow: desired position for nitrene transfer (sulfimidation). Purple: alkene prone for aziridination. Green: weak $\mathrm{C}-\mathrm{H}$ position $\left(\mathrm{BDE} \leq 85 \mathrm{kcal}^{\mathrm{mol}}{ }^{-1}\right)$. Grey: $\mathrm{C}-\mathrm{H}$ position with $85<\mathrm{BDE}<95 \mathrm{kcal} \mathrm{mol}^{-1}$. Yields based on ${ }^{1} \mathrm{H}$ NMR integration using 1,3,5-trimethoxybenzene as an internal standard. [a] $5 \mathrm{minutes}$ reaction time. [b] Same yield at $0^{\circ} \mathrm{C}(30 \mathrm{~min})$. [c] $2 \mathrm{~h}$. at $-61^{\circ} \mathrm{C}$. [d] $2 \mathrm{~h}$. at $-78^{\circ} \mathrm{C}$.

We next set out to further investigate the mechanism of the chemoselective sulfimidation using computational studies. Under the applied conditions $\mathbf{P P h}_{4}\left[\mathrm{Co}^{\text {"II'}}\left(\mathrm{TAML}^{\text {red }}\right)\right]$ is quantitatively converted to $\mathbf{P P h}_{4}\left[\mathbf{C o}^{\prime \prime \prime}\left(\operatorname{TAML}^{\mathrm{q}}\right)(\mathbf{N R})_{2}\right]$ upon reaction with PhINR $(\mathrm{R}=$ tosyl, nosyl) and the latter is a catalytic intermediate in nitrene transfer (aziridination). ${ }^{18}$ We therefore focused on the intermediacy of this anionic nitrene species during catalytic sulfimidation. Based on previously reported NEVPT2-CASSCF (multi-configurational $\mathrm{N}$-electron valence state perturbation theory corrected complete active space self-consistent field) and DFT (density functional theory) calculations we studied the [Co"'(TAML $\left.\left.{ }^{\text {red }}\right)\right]^{-}$catalyzed sulfimidation computationally with DFT at the BP86/def2-TZVP/disp3 level of theory at the triplet $(S=1)$ spin surface (see also $\mathrm{SI}){ }^{18,19}$ To compare the performance of the catalyst in $\mathrm{N}$-tosyl and $\mathrm{N}$-nosyl nitrene transfer, and to compare the mechanism with the previously reported aziridination, which operates via electronically asynchronous transition states, we calculated the full mechanisms for both the tosyl (Ts superscript) and nosyl (Ns superscript) substituted nitrenes (Scheme 4).

Mono-nitrene radical formation from $\mathbf{A}$ (reference point) and PhINR ( $R=$ Ns or Ts) via barrierless ligand-to-substrate singleelectron transfer affords $\mathbf{B}^{\text {Ns }}$ and $\mathbf{B}^{\text {Ts }}$ in exergonic reactions $\left(\Delta G^{\circ}=-29.4\right.$ and $-26.2 \mathrm{kcal} \mathrm{mol}^{-1}$, respectively). Reaction with another equivalent PhINR via a second ligand-to-substrate single-electron transfer event proceeds through a low-lying transition state $\left(\mathrm{TS} 1^{\mathrm{Ns}}\right.$ : $\Delta \Delta G^{\ddagger}=+12.0 \mathrm{kcal} \mathrm{mol}^{-1}, \mathrm{TS}^{\mathrm{Ts}}{ }^{\mathrm{Ts}}: \Delta \Delta G^{+}=$ $\left.+11.6 \mathrm{kcal} \mathrm{mol}^{-1}\right)$ to afford bis-nitrene radicals $\mathbf{C}^{\mathrm{Ns}}\left(\Delta G^{\circ}=-30.3\right.$ $\left.\mathrm{kcal} \mathrm{mol}{ }^{-1}\right)$ and $\mathbf{C}^{\top \mathbf{s}}\left(\Delta G^{\circ}=-25.1 \mathrm{kcal} \mathrm{mol}^{-1}\right)$. N-S bond formation on the formed bis-nitrene radical complexes is essentially barrierless at the SCF (self-consistent field) energy surface, and hence the free energy barrier should be primarily determined by (translational) entropy contributions (estimated at $\sim 7-10 \mathrm{kcal}$ $\left.\mathrm{mol}^{-1}\right)$. This yields the respective products as van der Waals adducts in a highly exergonic manner ( $D^{\text {Ns: }} \Delta G^{\circ}=-67.2 \mathrm{kcal}$ $\mathrm{mol}^{-1}$ and $\mathbf{D}^{\mathrm{Ts}}$ : $\left.\Delta G^{\circ}=-63.7 \mathrm{kcal} \mathrm{mol}^{-1}\right)$, concomitant with oneelectron reduction of the electrophilic TAML backbone. The SCF barrierless product formation is the result of the high oxidation state of the TAML ${ }^{9}$ in $\mathbf{C}$, thus precluding a barrier for initial substrate-to-ligand single-electron transfer. Endergonic release product $\mathbf{1}^{\mathrm{Ns}}\left(\Delta G^{\circ}=-58.7 \mathrm{kcal} \mathrm{mol}^{-1}\right)$ and $\mathbf{1}^{\mathrm{Ts}}\left(\Delta G^{\circ}=-55.9 \mathrm{kcal}\right.$ $\mathrm{mol}^{-1}$ ) from $\mathbf{D}$ regenerates the mono-nitrene radical $\mathbf{B}$, which can re-enter the bis-nitrene cycle. 


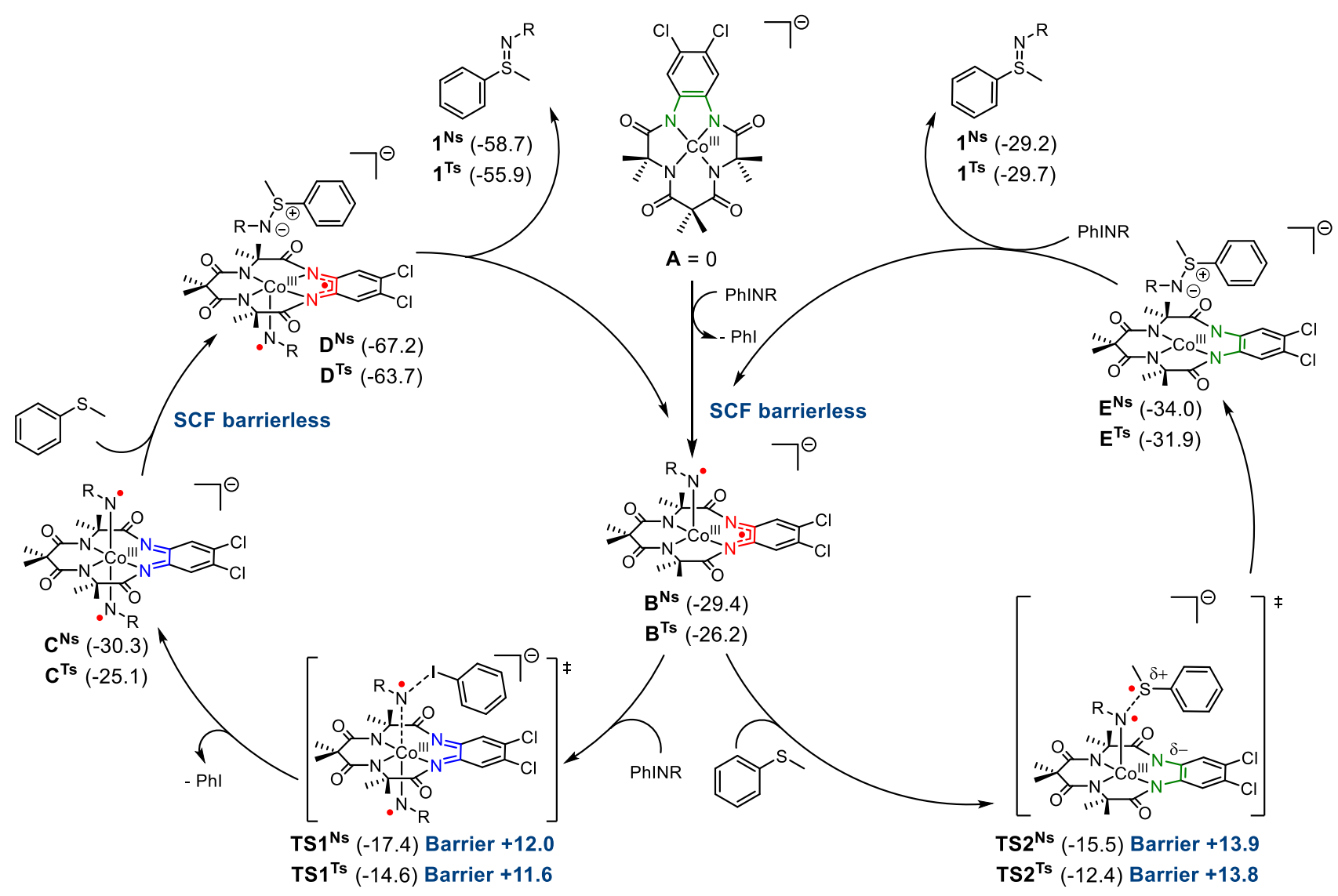

Scheme 4. Proposed mechanism for the [Co'II(TAML red)]- catalyzed sulfimidation of thioanisole to afford $1^{\text {Ns }}$ and $1^{\text {Ts }}$ via either a mono-nitrene (right) or bis-nitrene (left) pathway. Free energies $\left(\Delta G^{\circ}{ }_{298 \mathrm{~K}}\right.$ in $\left.\mathrm{kcal} \mathrm{mol}^{-1}\right)$ calculated with DFT at the BP86/def2-TZVP/disp3 (m4-grid) level of theory at the triplet $(S=1)$ spin surface.

Mono-nitrene radical $\mathbf{B}$ can also react directly with thioanisole via an electronically asynchronous transition state $\operatorname{TS}^{\mathrm{Ns}}\left(\Delta \Delta G^{\ddagger}=+13.9 \mathrm{kcal} \mathrm{mol}^{-1}\right)$ and $\mathrm{TS}^{\mathrm{Ts}}\left(\Delta \Delta G^{\ddagger}=+13.8 \mathrm{kcal}\right.$ $\left.\mathrm{mol}^{-1}\right)$. In this transition state, $\mathrm{N}-\mathrm{S}$ bond formation is preceded by substrate-to-ligand single-electron transfer and the nitrene- $N$ lone pair attacks the (partially) formed thioanisole radical cation. Simultaneously, single-electron transfer from the sulfide- $S$ to the nitrene- $N$ occurs to afford the zwitterionic sulfur ylide. During this process, the spin state on cobalt changes from low spin $(S=0$ in B) to intermediate spin ( $S=1$ in TS2 and $\mathbf{E})$. As a consequence, the total wavefunction adapts to a broken-symmetry solution, causing the formation of $\beta$-spin in a mainly sulfur-localized $\mathrm{N}-\mathrm{S}$ $\sigma^{*}$ orbital, which is then transferred to the $\alpha$-spin-bearing nonbonding orbital on the nitrene (see SI). The formation of the van der Waals adducts $E^{\text {Ns }}$ and $E^{\text {Ts }}$ is exergonic $\left(\Delta G^{\circ}=-34.0\right.$ and $-31.9 \mathrm{kcal} \mathrm{mol}^{-1}$, respectively) and product dissociation is again endergonic $\left(\Delta G^{\circ}=-29.2 \mathrm{kcal} \mathrm{mol}^{-1}\right.$ for $1^{\mathrm{Ns}}$ and $-29.7 \mathrm{kcal} \mathrm{mol}^{-1}$ for $\mathbf{1}^{\text {Ts }}$ ).

The positive charge buildup on the substrate due to electrophilic reaction of the nitrene intermediates, as also evident from the Hammett analysis, in combination with the electronically asynchronous transition state found for reaction of the mono-nitrene radical species with thioanisole, support a similar mechanism as described for styrene aziridination by [Co"'(TAML $\left.\left.{ }^{\text {red }}\right)\right]^{-18}$. However, N-S bond formation to afford the sulfimidation product via the bis-nitrene radical complex $(\mathbf{C})$ is barrierless at the SCF energy surface, which was not observed for the corresponding aziridination of styrene. The differences in activation and formation energies between the $\mathrm{N}$-tosyl and $\mathrm{N}$-nosyl nitrene transfer pathways are only small, and do not explain the faster reactions of PhINTs than PhINNs with thioanisole (Table 2, vide supra). However, this difference in reaction rates is most likely the result of the higher solubility of PhINTs $(8.2 \mathrm{mM})$ in comparison to PhINNs $(0.5 \mathrm{mM}$, see SI) in $\mathrm{CH}_{2} \mathrm{Cl}_{2}$, thus limiting the reaction rate to the rate of solvation of the iminoiodinane. As the kinetics of these reactions are likely determined by the low solubility of the nitrene precursors, we believe that the mono-nitrene pathway (from $\mathbf{B}$ to $\mathbf{E}$ via TS2) is the dominant pathway under the applied catalytic reaction conditions (i.e. in the presence of excess thioanisole). The significant Hammett $\rho^{+}$value of -0.57 seems inconsistent with near barrierless $\mathrm{N}-\mathrm{S}$ bond formation (bis-nitrene pathway), and hence also the experimental Hammett data are suggestive of a dominant mono-nitrene pathway. The lower calculated activation energies for sulfimidation $\left(+13.9 \mathrm{kcal} \mathrm{mol}^{-1}\right)$ in comparison to aziridination $\left(+14.6 \mathrm{kcal} \mathrm{mol}^{-1}\right)^{18}$ along the mono-nitrene pathways are consistent with the observed chemoselectivity in the inter- and intramolecular competition experiments (vide supra). The observed selectivity and calculated mechanisms are therefore also consistent with electrophilic behavior of the nitrene intermediates.

\section{Conclusion}

We have shown that $\mathbf{P P h}_{4}\left[\mathbf{C o}^{\text {III }}\left(\mathbf{T A M L}{ }^{\text {red }}\right)\right]$ is an effective catalyst for the sulfimidation of (alkyl)(aryl)-substituted sulfides under mild conditions $\left(25^{\circ} \mathrm{C}\right.$, aerobic, $\left.1.0 \mathrm{~mol} \%\right)$. TONs up to 900 and TOFs up to $640 \mathrm{~min}^{-1}$ are reported, demonstrating the 
stability and activity of the catalyst under practical conditions. Moreover, this is the first example of a cobalt-catalyzed sulfimidation reaction via nitrene transfer to sulfides. In the presence of alkenes and weak $\mathrm{C}-\mathrm{H}$ bonds, nitrene transfer proceeds chemoselectively towards the sulfide, as supported by inter- and intramolecular competition reactions, which we attribute to the lower oxidation potential of the sulfides and the electrophilic behavior of the nitrene radical intermediates. Electron-donating (Me, OMe) and -withdrawing $(\mathrm{F}, \mathrm{Cl})$ substituents on the aryl moiety in thioanisole derivatives are tolerated, and methyl substitution in thioanisole for ethyl, isopropyl, benzyl, ethylphenyl, and vinyl all afford the respective sulfimidation products in generally good yields. Sulfimidation of phenyl allyl sulfide leads to $[2,3]$-sigmatropic rearrangement to yield the $\mathrm{N}$-allyl-S-phenyl-thiohydroxylamine products. Latestage sulfimidation of ethyl-(4-(phenoxymethyl)-phenyl)-sulfane affords a small drug molecule in excellent yield. Hammett analysis indicates that positive charge buildup on the sulfide substrate occurs in the transition state leading to sulfimide product formation. Combined with the computational data, we suggest that the $\mathrm{N}-\mathrm{S}$ bond formation is initiated by substrate-toligand single-electron transfer (mono-nitrene pathway) in an electronically asynchronous transition state. The observed chemoselectivity is expected to contribute to new (late-stage) sulfimidation reactions wherein the oxidation potential of the functional groups determines the preferred nitrene-accepting moiety.

\section{Experimental Section}

General procedure for the catalytic sulfimidation reactions. A flamedried vial $(4 \mathrm{~mL})$ was charged with iminoiodinane $(48.0 \mu \mathrm{mol} ; 1.0$ eq. $)$, $\mathrm{CH}_{2} \mathrm{Cl}_{2}$ (1.8 mL; total concentration iminoiodinane of $24.0 \mathrm{mM}$ ), sulfide (72.0 $\mu \mathrm{mol} ; 1.5$ eq.; $100 \mu \mathrm{L}$ of a $720 \mathrm{mM}$ stock solution in $\mathrm{CH}_{2} \mathrm{Cl}_{2}$ ), $\mathrm{PPh}_{4}$ [Co'"'(TAML ${ }^{\text {red }}$ )] $(0.40 \mathrm{mg} ; 0.48 \mu \mathrm{mol} ; 1.0 \mathrm{~mol} \% ; 100 \mu \mathrm{L}$ of a $4.8 \mathrm{mM}$ stock solution in $\mathrm{CH}_{2} \mathrm{Cl}_{2}$ ) and closed with a cap. The reaction mixture was stirred under aerobic conditions at $25{ }^{\circ} \mathrm{C}$ for 30 minutes. 1,3,5Trimethoxybenzene $(0.67 \mathrm{mg} ; 4.0 \mu \mathrm{mol} ; 100 \mu \mathrm{L}$ of a $40.0 \mathrm{mM}$ stock solution in $\mathrm{CH}_{2} \mathrm{Cl}_{2}$ ) was added as an internal standard, the reaction mixture was filtered (syringe filter, PTFE, $0.45 \mu \mathrm{m}$ ) to remove unreacted iminoiodinane, concentrated under reduced pressure at $25^{\circ} \mathrm{C}$, dissolved in deuterated solvent, filtered (syringe filter, PFTE, $0.45 \mu \mathrm{m}$ ) and analyzed by ${ }^{1} \mathrm{H}$ NMR spectroscopy.

Supporting Information. Experimental details, synthetic procedures, NMR spectra, HRMS data, geometries (xyz coordinates) and energies of stationary points and transition states (DFT).

\section{Acknowledgements}

Financial support from The Netherlands Organization for Scientific Research (NWO TOP-Grant 716.015.001 to BdB) and the research priority area Sustainable Chemistry of the University of Amsterdam (RPA SusChem, UvA) is gratefully acknowledged. Ed Zuidinga is thanked for HRMS measurements.

Keywords: sulfimidation $\cdot$ cobalt $\cdot$ nitrene radical $\cdot$ redox-active ligand $\cdot$ chemoselectivity

\section{References}

[1] For selected reviews see: (a) V. Bizet, C. M. M. Hendriks, C. Bolm Chem. Soc. Rev. 2015, 44, 3378-3390. (b) H, Okamura, C, Bolm, Chem. Lett. 2004, 33, 482-487. (c) T. Katsuki, Chem. Lett. 2005, 34 1304-1309. (d) T. G. Driver, Org. Biomol. Chem. 2010, 8, 3831-3846. (e) T, Uchida, T. Katsuki, Chem. Rec. 2014, 14, 117-129.

[2] (a) M. Frings, C. Bolm, A. Blum, C. Gnamm, Eur. J. Med. Chem. 2017, 126, 225-245. (b) C. M. M. Hendriks, J. Hartkamp, S. Wiezerek, A.-D. Steinkamp, G. Rossetti, B. Lüscher, C. Bolm, Bioorg. Med. Chem. Lett. 2017, 27, 2659-2662.

[3] (a) S. Katsuyama, K. Sugino, Y. Sasazawa, Y. Nakano, H. Aono, K. Morishita, M. Kawatani, K. Umezawa, H. Osada, S. Simizu, FEBS Letters 2016, 590, 1152-1162. (b) I. Miyazaki, H. Okumura, S. Takagi, H. Osada, Nat. Chem. Biol. 2010, 6, 667-673.

[4] (a) T. Yamamoto, M.-A. Kakimoto, M. Okawara, Bull. Chem. Soc. Jpn 1979, 52, 841-845. (b) The first synthesis of sulfimides was reported in 1922, but their structure was not thoroughly proven: F. G. Mann, W. J. Pope, J. Chem. Soc., Trans. 1922, 121, 1052-1055.

[5] (a) H. Takada, Y. Nishibayashi, K. Ohe, S. Uemura, Chem. Commun 1996, 931-932. (b) H. Takada, Y. Nishibayashi, K. Ohe, S. Uemura, J. Org. Chem. 1997, 62, 6512-6518. (c) H. Takada, K. Ohe, S. Uemura, Angew. Chem. Int. Ed. 1999, 38, 1288-1289. (d) Y. Liu, H. Wang, X. Yang, Tetrahedron 2019, 75, 4697-4702. (e) T. L. Lam, K. C.-H. Tso, B. Cao, C. Yang, D. Chen, X.-Y. Chang, J.-S. Huang, C.-M. Che, Inorg. Chem. 2017, 56, 4253-4257.

[6] H. Nishikori, C. Ohta, E. Oberlin, R. Irie, T. Katsuki, Tetrahedron 1999, 55, 13937-13946.

[7] (a) M. Murakami, T. Uchida, T. Katsuki, Tetrahedron Lett. 2001, 42 7071-7074. (b) T. Ucida, Y. Tamura, M. Ohba, T. Katsuki, Tetrahedron Lett. 2003, 44, 7965-7968. (c) V. Bizet, L. Bugliono, C. Bolm, Angew. Chem. Int. Ed. 2014, 53, 5639-5642.

[8] (a) T. Bach, C. Körber, Eur. J. Org. Chem. 1999, 1033-1039. (b) J. Wang, M. Frings, C. Bolm, Angew. Chem. Int .Ed. 2013, 52, 8661-8665 (c) H. Lebel, H. Piras, M. Borduy, ACS Catal. 2016, 6, 1109-1112. (d) Y. Liu, C.-M. Che, Chem. Eur. J. 2010, 16, 10494-10501.

[9] (a) H. Okamura, C. Bolm, Org. Lett. 2004, 6, 1305-1307. (b) F. Collet, R. H. Dodd, P. Dauban, Org. Lett. 2008, 10, 5473-5476. (c) H. Lebel, H. Piras, J. Bartholoméüs, Angew. Chem. Int. Ed. 2014, 53, 7300-7304.

[10] G. Y. Che, C. Bolm, Org. Lett. 2005, 7, 4983-4985.

[11] C. C. Farwell, J. A. Mclntosh, T. K. Hyster, Z. J. Wang, F. H. Arnold, J. Am. Chem. Soc. 2014, 136, 8766-8771.

[12] Y. G. Cho, C. Bolm, Tetrahedron Lett. 2005, 46, 8007-8008.

[13] A. Yoshimura, C. L. Makitalo, M. E. Jarvi, M. T. Shea, P. S. Postnikov, G. T. Rohde, V. V. Zhdankin, A. Saito, M. S. Yusubov, Molecules 2019, 24, 979-989.

[14] S. Raghaven, S. Mustafa, K. Rathore, Tetrahedron Lett. 2008, 49 , 4256-4259

[15] O. G. Mancheño, C. Bolm, Chem. Eur. J. 2007, 13, 6674-6681.

[16] (a) N. P. van Leest, P. F. J. Epping, K. M. van Vliet, M. Lankelma, E. J. van den Heuvel, N. Heijtbrink, R. Broersen, B. de Bruin, Single-Electron Elementary Steps in Homogeneous Organometallic Catalysis. In Advances in Organometallic Chemistry, Vol. 70 (Eds.: P. J. Pérez, F. G. A. Stone, R. West), Elsevier, 2018; Vol. 70, pp 71-180. (b) P. F. Kuijpers, J. I. van der Vlugt, S. Schneider, B. de Bruin, Chem. Eur. J. 2017, 23, 13819-13829.

[17] For recent work see: (a) Y. Baek, A. Das, S.-L Zheng, J. H. Reibenspies, D. C. Powers, T. A. Betley, J. Am. Chem. Soc. 2020, 142, 11232-11243. (b) Y. Baek, T. A. Betley, J. Am. Chem. Soc. 2019, 141 7797-7806. (c) Y. Hu, K. Lang, C.-Q. Li, J. B. Gill, I. Kim, H.-J. Lu, K. B. Fields, M. K. Marshall, Q.-G. Cheng, X. Cui, L. Wojtas, X. P. Zhang, J. Am. Chem. Soc. 2019, 141, 18160-18169. (d) K. Lang, S. Torker, L. Wojtas, X. P. Zhang, J. Am. Chem. Soc. 2019, 141, 12388-12396. (e) Y. Hu, K. Lang, J.-R. Tao, M. K. Marshall, Q.-C. Cheng, X. Cui, L. Wojtas, X. P. Zhang, Angew. Chem. Int. Ed. 2019, 2019, 58, 2670-2674.

[18] N. P. van Leest, M. A. Tepaske, B. Venderbosch, J.-P. H. Oudsen, M. Tromp, J. I. van der Vlugt, B. de Bruin, ACS Catal. 2020, 10, 7449-7463. 
[19] N. P. van Leest, M. A. Tepaske, J.-P. H. Oudsen, B. Venderbosch, N. R. Rietdijk, M. A. Siegler, M. Tromp, J. I. van der Vlugt, B. de Bruin, J. Am Chem. Soc. 2020, 142, 552-563.

[20] (a) T. J. Collins, A. D. Ryabov, Chem. Rev. 2017, 117, 9140-9162. (b) T. J. Collins, R. D. Powell, C. Slebodick, E. S. Uffelman, J. Am. Chem. Soc. 1991, 113, 8419-8425.

[21] (a) N. L. Weinberg, H. R. Weinberg, Chem. Rev. 1968, 68, 449-523. (b) T. Fuchigami, S. Inagi, M. Atobe, Fundamentals and Applications of Organic Electrochemistry, Wiley \& Sons, Ltd.: West Sussex UK, 2014.

[22] (a) S. Hong, K. D. Sutherlin, A. K. Vardhaman, J. J. Yan, S. Park, Y.-M. Lee, S. Jand, X. Lu, T. Ohta, T. Ogura, E. I. Solomon, W. Nam, J. Am. Chem. Soc. 2017, 139, 8800-8803. (b) S. Hong, X. Lu, Y.-M. Lee, M. S Seo, T. Ohta, T. T. Ogura, M. Clémancey, P. Maldivi, J.-M. Latour, R. Sarangi, W. Nam, W. J. Am. Chem. Soc. 2017, 139, 14372-14375. (c) X. Lu, X.-X. Li, Y.-M. Lee, Y. Jang, M. S. Seo, S. Hong, K.-B. Cho, S. Fukuzumi, W. Nam, J. Am. Chem. Soc. 2020, 142, 3891-3904.

[23] H. Shi, J. Xie, W. W. Y. Lam, W.-L. Man, C.-K. Mak, S.-M. Yiu, H. K. Lee, T.-C. Lau, Chem. Eur. J. 2019, 24, 12895-12899.

[24] Assuming a $+47 \mathrm{mV}$ shift between $\mathrm{Ag} / \mathrm{AgCl}(0.1 \mathrm{M})$ and SCE. See: L. Meites. Handbook of Analytical Chemistry, McGraw Hill Text, 1963 section 5 .

[25] Based on the redox potentials only, a higher yield for sulfimidation of dimethylsulfide would be expected. However, the relatively low observed sulfimide yield (40\%) and formation of $\mathrm{NsNH}_{2}(55 \%)$ is most likely the result of hydrogen-atom transfer (HAT) from the transiently formed dimethylsulfide radical cation $\left(\mathrm{C}-\mathrm{H}\right.$ BDE $\left.=61.5 \mathrm{kcal} \mathrm{mol}^{-1}\right)$ to the nitrene radical intermediate. This HAT reaction does not occur for the transiently formed thioanisole radical cation $(\mathrm{C}-\mathrm{H} \mathrm{BDE}=72.8 \mathrm{kca}$ $\left.\mathrm{mol}^{-1}\right)$. See SI for additional details.

[26] At higher temperatures $\left(35^{\circ} \mathrm{C}\right)$ we observed a minor uncatalyzed background reaction in the formation of $1^{\text {Ts }}$ ( $3 \%$ in 30 minutes). The solvent was not varied as the yield of the desired product was already found to be $>90 \%$ and we have previously studied the formation and reactivity of the nitrene-radical complexes in detail in $\mathrm{CH}_{2} \mathrm{Cl}_{2}$.

[27] Luo, Y.-R. Comprehensive Handbook of Chemical Bond Energies, CRC Press: Boca Raton, 2007.

[28] M. Murakami, T. Katsuki, Tetrahedron Lett. 2002, 43, 3947-3949.

[29] L. P. Hammett, J. Am. Chem. Soc. 1937, 59, 69-103.

[30] X.-K. Jiang, Acc. Chem. Res. 1997, 30, 283-289 